\title{
IMPLEMENTASI PENDIDIKAN KARAKTER DI MAN MODEL MANADO
}

\section{The Implementation of Character Building Education in Man Model Manado}

\author{
Rosdiana \\ Balai Penelitian dan Pengembangan Agama Makassar \\ Jl. A.P. Pettarani No.72 Makassar \\ Email: rosdianalitbang03@gmail.com
}

Naskah diterima tanggal 30 April 2014. Naskah direvisi tanggal 29 September 2014. Naskah disetujui tanggal 7 Oktober 2014

\begin{abstract}
Abstrak
Penelitian ini bertujuan untuk mengetahui implementasi pendidikan karakter pada tataran sosialisasi yang dilakukan baik oleh Kemenag (Mapenda), Diklat Keagamaan Manado, Pengawas Madrasah, dan MAN Model Manado, serta proses pengimplementasian pendidikan karakter, faktor pendukung dan penghambat dalam pengimplementasiannya. Hasil penelitian menunjukkan bahwa implementasi pada tataran pengambil kebijakan telah dilakukan, pendidikan karakter telah diintegrasikan pada kurikulum melalui mata pelajaran dan kegiatan pengembangan diri (ekstrakurikuler). Di antara kendala dalam pendidikan karakter yakni kesiapan guru dalam teknik impelementasi pendidikan karakter masih sangat kurang serta wadah guru untuk mengkomunikasi berbagai hal termasuk pendidikan karakter secara teknis sangat diperlukan untuk menjalin jejaring kerja antar guru dan antar lembaga. Peningkatan kompetensi guru menjadi keharusan mengingat pentingnya pendidikan budaya dan karakter bagi siswa, baik dalam bentuk diklat, workshop, atau seminar.
\end{abstract}

Kata kunci: impelementasi, pendidikan, karakter

\begin{abstract}
This study aims to know the implementation of character building education performed by MORA, Madrasah Supervisors, and MAN model menado, the supportive and the hampering factors. The result shows that character building education has been integrated in the curriculum through self development, anextra curricular subject. However, the teacher knowledge and skill to implement the curriculum was lacking. Teacher needs to be facilitated to be able to communicate on issues of character building subjects with their own peers and other institutions. Their knowledge also needs to be improved through workshop, seminar and other trainings.
\end{abstract}

Keywords : implementation, character, education.

\section{PENDAHULUAN}

$\mathrm{S}$ ejak Menteri Pendidikan Nasional mendeklarasikan dimulainya pendidikan karakter bangsa pada tanggal 2 Mei 2010 (Hamid, 2013: 9), maka sejak itu pendidikan karakter sering diperbincangkan oleh kalangan akademisi maupun kalangan pejabat pemerintahan. Meskipun sebenarnya sudah termaktub dalam UUD RI 1945 pasal 31 ayat 3 yang menyatakan bahwa pemerintah mengusahakan dan menyelenggarakan satu sistem pendidikan nasional yang meningkatkan keimanan dan ketakwaan serta akhlak mulia dalam rangka mencerdaskan kehidupan bangsa yang diatur dalam Undang-Undang. Hal senada juga terdapat dalam redaksi defenisi pendidikan yang tercantum dalam Undang-Undang Nomor 20 Tahun 2003.

Menurut Undang-Undang Nomor 20 Tahun 2003 disebutkan bahwa Pendidikan adalah usaha sadar dan terencana untuk mewujudkan suasana belajar dan proses pembelajaran agar peserta didik secara aktif mengembangkan potensi dirinya 
untuk memiliki kekuatan spiritual keagamaan, pengendalian diri, kepribadian, kecerdasan, akhlak mulia, serta keterampilan yang diperlukan dirinya, masyarakat, bangsa dan negara. Jika memaknai redaksi ini, di dalam Undang-Undang ini sudah mencakup pendidikan karakter. Misalnya pada bagian kalimat terakhir dari defenisi pendidikan dalam Undang-Undang tentang SISDIKNAS (Sistem Pendidikan Nasional) ini, yaitu memiliki kekuatan spiritual keagamaan, pengendalian diri, kepribadian, kecerdasan, akhlak mulia, serta keterampilan yang diperlukan dirinya, masyarakat, bangsa dan negara. Definisi pendidikan tersebut setidaknya memberikan arah tujuan pendidikan nasional pada tiga dimensi yang tak terpisahkan, yaitu dimensi ketuhanan, dimensi personal dan dimensi sosial.

Bila ternyata kini banyak kalangan yang kembali memperbincangkan tentang karakter, hal itu sangat wajar dengan melihat fenomena dekadensi moralitas siswa secara nasional. Faktanya adalah perilaku siswa sangat bertentangan dengan tujuan pendidikan. Di beberapa media cetak maupun elektronik sering memberitakan hampir di setiap kota di Indonesia terjadi tawuran antara pelajar, tawuran antar geng motor dan perkelahian antar siswa sekolah

Paling tidak mengurangi, masalah budaya dan karakter bangsa yang dibicarakan itu adalah pendidikan. Pendidikan, yang dianggap sebagai alternatif yang bersifat preventif karena membangun generasi baru bangsa yang lebih baik. Sebagai alternatif yang bersifat preventif, pendidikan diharapkan dapat mengembangkan kualitas generasi muda dalam berbagai aspek yang dapat memperkecil dan mengurangi penyebab berbagai masalah budaya dan karakter bangsa. Memang diakui bahwa hasil dari pendidikan akan terlihat dampaknya dalam waktu yang tidak segera, tetapi memiliki daya tahan dan dampak yang kuat di masyarakat.

Tuntutan akuntabilitas publik terhadap kinerja lembaga pendidikan, tantangan standar peningkatan mutu pendidikan, dan sedikitnya tenaga, waktu dan sarana yang dimiliki oleh lembaga pendidikan dan guru, menantang setiap pendidik untuk mendesain pendidikan karakter di sekolah tanpa melalaikan tujuan penting yang ingin diraih dalam setiap pendidikan. Pendidikan karakter tidak dapat dipahami sebagai bagian tambahan bagi pengembangan keunggulan akademi siswa, tetapi menjadi satu bagian integral dalam rangka pendidikan kemanusiaan (Koesoema, 2012: xi).
Penelitian ini bertujuan untuk mengungkap tentang pendidikan karakter, melalui komponen: pada tataran sosialisasi yang dilakukan baik oleh Kemenag (Mapenda), Diklat Keagamaan Manado, Pengawas Madrasah, dan MAN Model Manado. Kemudian mengungkap tentang implementasi pendidikan karakter pada MAN Model Manado tentang pengintegrasian pendidikan karakter pada kurikulum, dan proses pengimplementasian pendidikan karakter apakah sesuai dengan harapan oleh sebab itu dalam penelitian ini juga akan mengungkap faktor pendukung dan penghambat dalam pengimplementasian pendidikan karakter pada MAN Model Manado.

\section{Tinjaun Pustaka}

Kata Karakter diambil dari bahasa Inggris character, yang juga berasal dari bahasa Yunani charakter. Awalnya, kata ini digunakan untuk menandai hal yang mengesankan dari koin (keping uang). Belakangan, secara umum istilah character digunakan untuk mengartikan hal yang berbeda antara satu hal dan yang lainnya, dan akhirnya juga digunakan untuk menyebut kesamaan kualitas pada tiap orang yang membedakan dengan kualitas lainnya (Mu'in, 2011: 162).

Pendidikan budaya dan karakter bangsa dilakukan melalui pendidikan nilai-nilai atau kebajikan yang menjadi nilai dasar budaya dan karakter bangsa. Kebajikan yang menjadi atribut suatu karakter pada dasarnya adalah nilai. Oleh karena itu pendidikan budaya dan karakter bangsa pada dasarnya adalah pengembangan nilai-nilai yang berasal dari pandangan hidup atau ideologi bangsa Indonesia, agama, budaya, dan nilai-nilai yang terumuskan dalam tujuan pendidikan nasional (Kementerian Pendidikan Nasional, 2010: 7).

Pendidikan karakter diartikan sebagai the deliberate us of all dimension of school life to foste optimal charakter development (usaha kita secara sengaja dari seluruh dimensi kehidupan sekolah untuk membantu perkembangan karakter dengan optimal). Hal ini berarti bahwa untuk mendukung pekembangan karakter peserta didik harus melibatkan seluruh komponen di sekolah baik dari isi kurikulum (the content of the curriculum), proses pembelajaran (the procces of instruction), kualitas hubungan (the quality of relationships), penanganan mata pelajaran (the handling of disipline), pelaksanaan aktivitas ko-kurikuler, serta etos seluruh lingkungan sekolah (Zubaedi, 2011: 14) 
Karakter yang didefinisikan Ryan dan Bohling dalam Saimroh, dkk (2013: 8) mengandung tiga unsur, yaitu mengetahui kebaikan (knowing the good), mencintai kebaikan (loving the good) dan melakukan kebaikan (doing the good). Karakter adalah watak, sifat atau hal-hal yan memang sangat mendasar yang ada pada diri seseorang. Terdapat pesamaan antara pendidikan karakter, moral akhlak dan budi pekerti. Sekalian mempunyai persamaan namun mempunyai akar yang berbeda.

Pendidikan karakter bukanlah sebuah proses menghafal materi soal ujian, dan teknik-teknik menjawabnya. Pendidikan karakter memerlukan pembiasaan. Pembiasaan untuk berbuat baik; pembiasaan untuk berlaku jujur, kesatria; malu berbuat curang; malu bersikap malas; malu membiarkan lingkungannya kotor. Karakter tidak terbentuk secara instan, tapi harus dilatih secara serius dan proporsional agar mencapai bentuk dan kekuatan yang ideal (Husaini, 2010: 25).

Fungsi pendidikan budaya dan karakter bangsa adalah: 1) pengembangan: pengembangan potensi peserta didik untuk menjadi pribadi berperilaku baik; ini bagi peserta didik yang telah memiliki sikap dan perilaku yang mencerminkan budaya dan karakter bangsa; 2) perbaikan: memperkuat kiprah pendidikan nasional untuk bertanggung jawab dalam pengembangan potensi peserta didik yang lebih bermartabat; dan 3) penyaring: untuk menyaring budaya bangsa sendiri dan budaya bangsa lain yang tidak sesuai dengan nilai-nilai budaya dan karakter bangsa yang bermartabat.

Tujuan pendidikan budaya dan karakter bangsa adalah: 1) mengembangkan potensi kalbu/ nurani/afektif peserta didik sebagai manusia dan warganegara yang memiliki nilai-nilai budaya dan karakter bangsa; 2) mengembangkan kebiasaan dan perilaku pesertadidikyang terpujidan sejalan dengan nilai-nilai universal dan tradisi budaya bangsa yang religius; 3) menanamkan jiwa kepemimpinan dan tanggung jawab peserta didik sebagai generasi penerus bangsa; 4) mengembangkan kemampuan peserta didik menjadi manusia yang mandiri, kreatif, berwawasan kebangsaan; dan 5) mengembangkan lingkungan kehidupan sekolah sebagai lingkungan belajar yang aman, jujur, penuh kreativitas dan persahabatan, serta dengan rasa kebangsaan yang tinggi dan penuh kekuatan (dignity). Oleh Nashir (2013: 7) pendidikan karakter harus diletakkan secara keseluruhan dengan pembangunan karakter bangsa (nation and character building) dan dalam kaitan ini betapa penting fungsi lembaga pendidikan sebagai bagian strategis dari strategi kebudayaan dalam embangung bangsa.

Hal yang sama menurut Mulyasa bahwa pendidikan karakter bertujuan untuk meningkatkan mutu proses dan hasil pendidikan yang mengarah pada pembentukan karakter dan ahlak mulia peserta didik secara utuh, terpadu, dan seimbang, sesuai dengan standar kompetensi lulusan pada setiap satuan pendidikan. Melalui pendidikan karakter peserta didik diharapkan mampu secara mandiri meningkatkan dan menggunakan pengetahuannya, mengkaji dan menginternalisasikan nilai-nilai karakter dan akhlak mulia sehingga terwujud dalam prilaku sehari-hari (Mulyasa, 2011: 9).

Dalam rangka lebih memperkuat pelaksanaan pendidikan karakter pada satuan pendidikan telah teridentifikasi 18 nilai yang bersumber dari agama, Pancasila, budaya, dan tujuan pendidikan nasional, yaitu: (1) Religius, (2) Jujur, (3) Toleransi, (4) Disiplin, (5) Kerja keras, (6) Kreatif, (7) Mandiri, (8) Demokratis, (9) Rasa Ingin Tahu, (10) Semangat Kebangsaan, (11) Cinta Tanah Air, (12) Menghargai Prestasi, (13) Bersahabat/Komunikatif, Cinta Damai, (15) Gemar Membaca, (16) Peduli Lingkungan, (17) Peduli Sosial, (18) Tanggung Jawab.

Prilaku seseorang yang berkarakter pada hakekatnya merupakan perwujudan fungsi totalitas psikologi yang mencakup seluruh potensi individu manusia (kognitif, afektif, konatif, dan psikomotorik) dan fungsi totalitas sosial kultural dalam konteks interaksi (dalam keluarga, satuan pendidikan, dan masyarakat) dan berlangsung sepanjang hayat. Konfigurasi karakter dalam konteks totalitas proses psikologi dan sosial-kultural dapat dikelompokkan dalam olah hati (spirtual an emotional developoment), olah pikir (intellectual development), olah raga dan kinestetik (physical and kinestetic development), dan olah rasa dan karsa (affective and creativity development). Keempat proses psokososial (olah hati, olah pikir, olah raga, dan olah rasa dan karsa) tersebut secara holistik dan koheren memiliki saling keterkaitan dan saling melengkapi, yang bermuara pada pembentukan karakter yang menjadi perwujudan dari nilai-nilai luhur (Kementerian Pendidikan Nasional, Desain Induk Pendidikan Karakter, 2010: 9).

\section{METODE PENELITIAN}

Penelitian ini menggunakan pendekatan kualitatif dan jenis data yang dibutuhkan adalah data primer dan data sekunder. Data sekunder 
diperoleh melalui kajian pustaka, yaitu melalui buku, catatan yang berhubungan dengan pendidikan karakter. Data primer diperoleh melalui wawancara mendalam dengan informan yang berhubungan dengan kebijakan terkait pendidikan karakter, implementasi pendidikan karakter, dan faktor pendukung dan penghambat di dalam pengimplementasian pendidikan karakter pada satuan pendidikan di madrasah. Sumber data primer adalah sumber data yang langsung memberikan data (Sugiyono, 2010: 137) dan untuk melengkapi data primer dan data sekunder dilakukan observasi. Pengolahan dan analisis data yang di peroleh disesuaikan dengan sifatnya, terutama hasil wawancara yang berhubungan dengan implementasi pendidikan karakter, faktor pendukung dan penghambat implementasi pendidikan karakter, disesuaikan dengan jenis dan tujuan penelitian. Demikian pula dilakukan pengelompokan data dengan memperhatikan data yang sejenis dan data yang memiliki perbedaan kemudian diidentifikasi keterkaitan diantara data tersebut. Interpretasi data dilakukan tanpa mengabaikan data emik dan etik.

\section{PEMBAHASAN}

\section{Profil MAN Model Manado}

MAN Model Manado terletak di Jl. Hasanuddin 14. Kecamatan Tuminting Kelurahan Islam lingkungan III Kota Manado Provinsi Sulawesi Utara kode pos 95236. Keberadaan MAN Model dipusat Kota Manado, pusat pemerintahan, pusat perdagangan dan juga pariwisata di Sulawesi Utara. Jarak MAN Model Manado dari pusat kota kurang lebih $3 \mathrm{~km}$, dan dari bandara Sam Ratulangi kurang lebih $10 \mathrm{~km}$.

Lokasi MAN Model Manado merupakan ex sekolah Cina, yang diserahkan kepada pemerintah Republik Indonesia pada tahun 1965. Pada awalnya digunakan untuk sekolah PGAN (Pendidikan Guru Agama Negeri) Manado hingga pada tahun 1992, kemudian beralih fungsi berdasarkan Surat Keputusan (SK) Menteri Agama Republik Indoensia No 42 Tahun 1992 tanggal 27 Januari 1992 menjadi MAN Manado. Kemudian dalam perkembangannya MAN Manado terpilih bersama 35 MAN di Indonesia lainnya sebagai Madrasah Aliyah Negeri Model, melalui surat keputusan Direktur Jenderal Pembinaan Kelembagaan Agama Islam No IV/PP.00.6/KEP/17A/98 tertanggal 20 Februari 1998 tentang penetapan 35 MAN menjadi MAN Model.
Dewasa ini MAN Model Manado telah terakreditasi A pada Tahun 2012 dengan NSM/ NSS 311176004001 dan NPSN 60725207. Dengan keberadaan MAN Manado hingga menjadi MAN Model Manado telah dipimpin oleh beberapa kepala sekolah diantaranya: Drs. Suwarto (tahun 1992-1995), Drs. H. Muh. Sukarmi (tahun 19951996), Imran Akili, S.Ag (tahun 1996-1999), Drs. Sjamsuddin N.Tuli (tahun 1999-2002), Drs. Abd. Rahim, M.Pd (tahun 2002-2006), Drs. Alex K. Usman, M.Pd (tahun 2008-2012), H. Mashar Kinontoa, S.Ag), dan Dra. Sarpin Hamzah (2012-sekarang).

Lokasi yang ditempati MAN Model Manado merupakan tanah negara dan Departemen Agama RI/Kantor Wilayah Departemen Agama Provinsi Sulawesi Utara sebagai Hak Pakai. Luas keseluruhan sesuai dengan sertifikat tanah No 2 tahun 1983 adalah $10.073 \mathrm{~m} 2$ (termasuk Kantor Urusan Agama). Luas bangunan MAN Model Manado adalah seluas $5.179 \mathrm{~m} 2$.

Bangunan gedung MAN Model pada umumnya masih dalam kondisi baik karena sudah merupakan bangunan baru. Pembangunan gedung baru dan rehab dimulai sejak tahun 2000 hingga sekarang. Keadaan gedung MAN model Manado yang dimiliki sekarang di antaranya: gedung kantor dua lantai (luas $460 \mathrm{~m} 2$ ), gedung laboratorium dan perpustakaan, gedung tata busana, gedung tata boga, gedung keteramilan meubelir, ruang belajar 18 kelas, gedung PSBB, asrama siswa putra putri, Masjid, rumah dinas, 2 lapangan basket, lapangan bulu tangkis, kantin dan taman.

Keadaan tenaga pendidik/guru MAN Model Manado untuk tahun ajaran 2013-2014 secara keseluruhan berjumlah 66 orang merupakan guru PNS 47 orang dan Non PNS 19 orang, tenaga pendidikan pada MAN Model tersebut dominan sudah tersertifikasi dan hanya sebagian kecil (sekitar 7 orang) yang masih sementara dalam proses sertifikasi dan pengurusan. Di samping itu tenaga pendidik memiliki latar belakan pendidikan S1 dan lebih kurang 9 orang yang memiliki latar belakang pendidikan S2. Untuk tenaga adimistrasi/ tenaga kependidikan terdiri TU, bendahara, tenaga perpustakaan, cleaning servis, satpam, draiver secara keseluruhan berjumlah 21 orang.

Terkait peningkatan kompetensi guru dalam workshop, seminar dan diklat baik dalam skala internal madrasah maupun lokal dan nasional cukup sering diikuti oleh guru MAN Model, khusus pada peningkatan kompetensi guru dalam pendidikan 
karakter dari informan hanya sebagin kecil yang pernah mengikuti diklat maupun seminar. Untuk Diklat yang diikuti yakni pada Diklat Keagamaan Manado, dan workshop KTSP yang diselenggarakan oleh Balai Litbang Agama Makassar.

Keadaan siswa MAN Model untuk tahun ajaran 2013-2014 secara keseluruhan berjumlah 1113 siswa, dengan rincian masing-masing tingkatan untuk kelas $\mathrm{X}$ berjumlah 4 siswa yang terdiri 13 kelas, kelas XI berjumlah 340 siswa terdiri 10 kelas, dan kelas XII berjumlah 298 terdiri 10 kelas. Penjurusan pada MAN Model yang telah menjadi program madrasah di antaranya IPA, IPS, Bahasa, dan Agama. Pada masing-masing tingatan tersebut terdapat kelas olimpiade dan kelas bilingual. Kedua kelas tersebut merupakan kelas program khusus dengan memiliki beberapa program tambahan dibandingkan dengan kelas reguler/umum. Diantara program tambahan adalah tambahan jam pelajaran dibandingkan kelas lain. Selain itu, kelas ini juga merupakan kelas persiapan bagi siswa ntuk ikut lomba olimpiade sains dan berbagai perlombaan lain.

Berbagai prestasi telah diukir oleh MAN Model Manado baik dibidang akademik juga bidang keagamaan maupun dibidang olah raga. Diantaranya: marcing band, lomba olimpiade sains (kimia, fisika, matematika, dan biologi), cerdas cermat, lomba bahasa Jepang dan Jerman, pidato bahas Inggris, lomba debat, dalam bidang keagamaan (lomba hafalan surah, adzan, qiraat Alquran, tilawah, syarah, fahmil, kaligrafi, dll), dan berbagai prestasi dibidang olah raga yakni badminton, futsal, baseket, tenis meja, dll. Prestasi siswa dalam akademik lainnya adalah tingkat kelulusan siswa MAN Model Manado pada ujian nasional, hal ini terlihat dari tingkat kelulusan siswa. Untuk tahun ajaran 2012-2013 kelulusan siswa MAN Model Manado lulus 100\% dengan jumlah peserta ujian nasional 474 siswa, demikian juga tahun ajaran sebelumnya 2011-2012 lulus $100 \%$, dan untuk tahun ajaran 2010-2011 hanya satu orang yang tidk lulus.

Kurikulum sebagai panduan yang wajib diikuti oleh guru sebagai patokan dalam melaksanakan pembelajaran oleh MAN Model Manado berpijak pada kurikulum KTSP (kurikulum Tingkat Satuan Pembelajaran) yang sudah dikembangan berdasarkan kebutuhan dan kondisi madrasah. Kurikulum inilah yang masingmasing guru mengimplementasikannya dalam pembelajaran berdasarkan struktur kurikulum yang telah disepakati bersama. Struktur kurikulum yang telah ditetapkan MAN Model Manado pada kelas unggulan dan reguler, terdapat penambahan jam pelajaran (pengayaan) pada kelas-kelas ungulan tersebut. Untuk kelas XII penambahan jam dilakukan pada mata pelajaran yang diujikan dalam ujian nasional dengan jam yang sama dengan kelas tingkatan lain.

Mata pelajaran muatan lokal yang merupakan kegiatan kurikuler dimaksudkan untuk mengembangkan kompetensi yang disesuaikan dengan ciri khas dan potensi daerah, termasuk keunggulan daerah, yang materinya disesuaikan menjadi bagian mata pelajaran tersendiri. Substansi muatan lokal ditentukan sendiri oleh satuan pendidikan, tidak terbatas pada mata pelajaran ketrampilan. Muatan lokal merupakan mata pelajaran, sehingga satuan pendidikan harus mengembangankan standar konpetensi dan komptensi dasar untuk setiap jenis muatan lokal yang diselenggarakan. Satuan pendidikan dapat menyelenggarakan satu mata pelajaran muatan lokal setiap semester.

Dengan mengacu pada substansi yang ada, MAN Model Manado memberikan muatan lokal berdasarkan kebutuhan dan budaya daerah yaitu memberikan wawasan dan keterampilan yang utuh terhadap pengusaan keterampilan yakni tata boga, tata busana, keterampilan mebulir, dan pertamanan sesuai kebutuhan peserta didik dan tuntutan masyarakat lokal dan nasional.

Muatan lokal yang dikembangkan MAN Model Manando adalah pemenuhan kebutuhan peserta didik akan keterampilan pemanfaatan teknologi yang ada di MAN Model Manando dan tuntutan kebutuhan lokal daerah Sulawesi Utara dalam menyongsong tantangan global. Pemilihan mata pelajaran mutan lokal bagi siswa yakni keterampilan tata boga, tata busana, mebel, dan pertamanan.

Beban belajar yang diatur di MAN Model Manado dengan menggunakan sistem paket yaitu sistem penyelenggaraan pendidikan yang peserta didiknya diwajibkan mengikuti seluruh program pembelajaran yang ada dengan beban belajar yang sudah ditentukan untuk setipa kelas sesuai dengan struktur kurikulum yang berlaku pada MAN Model Manado. Beban belajar setiap mata pelajaran pada sistem paket dinyatakan dalam satuan jam pembelajaran.

Beban belajar dirumuskan dalam bentuk satuan waktu yang dibutuhkan oleh peserta 
didik untuk mengikuti program pembelajaran melalui sistem tatap muka, penugasan terstruktur, dan kegiatan mandiri tidak terstruktur. Semua itu dimaksudkan untuk mencapai standar kompetensi lulusan dengan memperhatikan tingkat perkembangan peserta didik.

Kegiatan tatap muka adalah kegiatan pembelajaran yang merupakan proses inetraksi aantara peserta didik dengan pendidik. Beban belajar kegiatan tatap muka perjam pembelajaran di MAN Model Manado berlangsung selama 45 menit. Pada aspek ketuntasan belajar oleh MAN Model Manado menentukan kriteria ketuntasan minimal dengan mempertimbangkan: Intake siswa, yaitu tingkat kemampuan rata-rata siswa, yang dilihat dari nilai yang diperoleh siswa pada ulangan semester, untuk kelas X diambil dari nilai UN SMP/MTs, dan nilai hasil seleksi penerimaan siswa baru. Tingkat kompleksitas, yaitu tingkat kerumitan/kesulitan materi pelajaran, tingkat kompleksitasnya tinggi apabila memerlukan penalaran dan kecermatan dalam mempelajarinya. Kemampuan sumber daya pendukung dalam penyelenggaraan pembelajaran, yaitu ketersediaan tenaga, sarana dan prasarana pendidikan, biaya operasional, manajemen sekolah, kepedulian stakeholder sekolah, dan lain-lain.

Jumlah ketuntasan minimal mata pelajaran yang telah ditentukan oleh MAN Model Manado pada setiap mata pelajaran berbeda antara kelas reguler dan kelas unggulan, kelas unggulan tersebut memiliki nilai ketuntasan belajar lebih tinggi dibandingkan kelas reguler. Perbedaan nilai tersebut antara 4 sampai 5 angka. Secara umum standar kriterian ketuntasan minimal mata pelajaran MAN Model Manado adalah antara 75 sampai 80.

\section{Implementasi Pendidikan Karakter Kebijakan Terhadap Pendidikan Karakter Kemenag Provinsi Sulawesi Utara}

Karakter sebagai suatu moral atau akhlak dibangun di atas berbagai kebajikan memiliki makna ketika dilandasi atas nilai-nilai yang berlaku dalam budaya (bangsa). Karakter bangsa Indonesia adalah karakter yang dimiliki warga negara bangsa Indonesia berdasarkan tindakan-tindakan yang dinilai sebagai suatu kebajikan berdasarkan nilai yang berlaku di masyarakat dan bangsa Indonesia. Oleh karena itu, Pendidikan Budaya dan Karakter Bangsa diarahkan pada upaya mengembangkan nilai-nilai yang mendasari suatu kebajikan sehingga menjadi suatu kepribadian diri warga negara.
Pada tataran Kementerian Agama Provinsi Sulawesi Utara beberapa kebijakan juga telah menjadi agenda utama terkait sosialisasi dan implemetasi pendidikan karakter pada bidangbidang terkait (mapenda) terutama pada tataran satuan pendidikan.

Menurut Drs. H. Sya'ban Mauluddin, M.Pd.I (Kanwil Kemenag Prov. Sulawesi Utara: Implementasi pembelajaran karakter pada tataran kebijakan yang diambil tentu mengikuti petunjuk yang ada. Sosialisasi dilakukan dari top down pada tataran atas terhadap satuan pendidikan. Melalui kasi pendidikan hal ini dilakukan kepada sekolahsekolah dan guru-guru di sekolah masing-masing, dan melalui pengawas satuan pendidikan sebagai ujung tombak, kasi mapenda dan elemennya. Bentuk kegiatan sosialisasi melalui pengarahanpengarahan pada kegitan-kegitan yang ada, seminar, workhop atau pelatihan-pelatihan.

Kepedulian masyarakat mengenai pendidikan budaya dan karakter bangsa telah pula menjadi kepedulian pemerintah. Berbagai upaya pengembangan pendidikan budaya dan karakter bangsa telah dilakukan di berbagai lembaga pemerintah, terutama di Kementrian Pendidikan Nasional. Upaya pengembangan itu berkenaan dengan berbagai jenjang dan jalur pendidikan walaupun sifatnya belum menyeluruh. Keinginan masyarakat dan kepedulian pemerintah mengenai pendidikan budaya dan karakter bangsa, akhirnya berakumulasi pada kebijakan pemerintah mengenai pendidikan budaya dan karakter bangsa dan menjadi salah satu program unggulan pemerintah, paling tidak untuk masa 5 (lima) tahun mendatang. Pedoman tersebut adalah rancangan operasionalisasi kebijakan pemerintah dalam pendidikan budaya dan karakter bangsa.

\section{Balai Diklat Keagamaan Manado}

Balai Pendidikan dan Latihan Keagamaan Manado yang memiliki fungsi sebagai pengayom bagi guru-guru khusus dalam meningkatkan kompetensi guru-guru dalam berbagai aspek. Tidak terkecuali pada aspek peningkatan pengetahuan guru akan stnadar kurikulum yang berlaku sesuai dengan program pemerintah.

Pembelajaran pendidikan karakter sesuai dengan yang digulirkan oleh pemerintah sudah ditindaklanjuti oleh Balai Diklat Keagamaan Manado sejak tahun 2011 dan diajarakan sebagai satu mata diklat kepada guru-guru. Pembelajaran yang dilakukan melalui pembiasaan, pengembangan diri, 
praktek (memlaui instrumen yang dikembangkan dan dilengkapi dengan indikator pencapaian). Program diklat bagi guru-guru misalnya pada mata pelajaran Bahasa Arab dari kompetensi dasar dilekatkan dengan karakter yang ingin dicapai. Pada madrasah memiliki mata pelajaran dengan rumpun mata pelajaran umum, rumpun mata pelajaran agama, dan rumpun sosial dan eksak.

Menurut Drs. Rusli, M.Si (Koordinator Widya Iswara Balai Diklat Manado) untuk pembelajaran pendidikan karakter pada tataran Widya Iswara (memiliki panduan dan silabus sebagai pedoman bagi widya iswara) tetapi pada kenyataannnya para Widya Iswara masih mencari strategi dan pola pembelajaran yang diterapkan kepada peserta diklat. Pengembangan-pengembangan pembelajaran pendidikan karakter lebih di fokuskan pada masingmasing pemateri (widya iswara).

Program diklat keagamaan Manado pada pendidikan karakter merupakan mata ajar tersendiri. Untuk guru tingkatan SD diajarkan 4 jam, untuk SMP dan SMA 4-6 jam pelajaran, yang berbentuk materi dan praktek. Materi pendidikan karakter sendiri menjadi mata ajar tersendiri diprogramkan sejak tahun 2011. Kendala dominan yang dihadapi guru adalah lebih kepada metodologi yang digunakan dalam pembelajaran, pada diklat-diklat yang dilakukan adalah memberikan materi selain teori adalah memberikan bagaimana mendesain materi, bahan ajar, kemudian dilanjutkan dengan micro teaching sesama guru, dan bagaimana pembelajaran di kelas dengan praktek, kemudian dengan materi game.

\section{Pengawas Madrasah}

Sebagai salah satu komponen yang memiliki peranan vital pada peningkatan mutu pendidikan di sekolah dan madrasah pengawas memiliki kompetensi untukitu. MenurutH. Mashar Kinontoa, S.Ag (Ketua Pokjawas Provinsi/pengawas MA) yang mengawasi MA dan MTs sebanyak 15 madrasah. Dalam kepengawasannya satu semester berjalan akan di analisa 18 standar proses penilaian mana yang tidak mencapai standar, dan akan ditindak lanjuti pada pengawasan semester selanjutnya. Dan memiliki buku laporan pengawas, untuk bidang akademik dilakukan bersama pengawas lain (berdua dengan pengawas lain (pak Suharto)) untuk 15 madrasah dan bidang manajerial kepala sekolah masing-masing madrasah 7 madrasah. Pengawasan dilakukan minimal satu kali sebulan pada sekolah yang sama.
Proses sosilisasi berkaitan pendidikan karakter dilakukan sejak tahun ajaran 20122013, tepatnya pada semister ganjil, dan sudah diterapkan pada silabus dan RPP guru-guru madrasah. Masing-masing karakter yang akan diimplementasikan sudah disarankan kepada guru untuk mengintergasikan pada SK dan KD pada masing-masing mata pelajaran.

Peran pengawas pada pendidikan karakter, khusus untuk madrasah melakukan pendampingan ini juga akan berpengaruh pada akreditasi madrasah, jika ini telah dilengkapi maka kemudahan akan diperoleh ketika akan akreditasi, diantaranya kelengkapan kurikulum itu sendiri dan ada beberapa standar yang harus dipenuhi oleh guru, dan sebagai pengawas berusaha untuk memenuhi standar itu.

\section{MAN Model Manado}

Pada tataran satuan pendidikan MAN Model Manado sosialisasi terkait pendidikan karakter telah berjalan seiring dengan adanya sosialisasi yang dilakukan oleh pihak terkait (Kemenag Provinsi Sulawesi Utara, Mapenda, dan pengawas madrasah). Menurut Dra. Sarpin Hamzah (Kepala Sekolah MAN Model Manado) untuk pendidikan karakter sudah terimplementasi dalam semua mata pelajaran, kegiatan ekstrakurikuler maupun kegiatan pengembangan lain, yang di rencanakan bagi semua guru-guru dan perencanaanya diperkuat pada pertemuan guru-guru melalui MGMP (Musyawaah Guru Mata Pelajaran). Untuk MGMP internal madrasah cukup aktif tetapi untuk MGMP lintas kementerian (Diknas) ini belum ada. Lebih lanjut menurut beliau pembentukan karakter bagi siswa sangat penting sebagai upaya dalam memberi nilai tambah dalam membentuk kepribadian siswa kelak, penguatan pendidikan karakter bagi siswa khusus Kota Manado tentu sangat dibutuhkan, dengan kondisi Kota Manado sebagai salah satu daerah tujuan wisata nasional dan internasional cukup memberi dampak terhadap perkembangan pergaulan anak muda dewasa ini, penanaman nilai-nilai karakter yang akan mengakar pada siswa setidaknya akan memberi benteng untuk memfilter berbagai dampak tersebut.

Selain, program implementasi pendidikan karakter yang sudah berjalan terdapat program tambahan yang akan menjadi program tambahan yakni pendidikan anti koupsi. Program pengimplementasian pendidikan anti korupsi dalam kurikulum MAN Model Manado masih pada tataran sosialisasi dan pada tahun ajaran 2013-2014 akan diimplemenasikan di dalam pembelajaran. 


\section{Implementasi Pendidikan Karakter Pada MAN Model Manado \\ Pengembangan Pendidikan Karakter Utama Pada MAN Model Manado}

Pendidikan budaya dan karakter bangsa sebagai sebuah aturan yang ditetapkan untuk diimplementasikan pada semua satuan pendidikan mulai digulirkan oleh Kementerian Pendidikan sejak tahun 2010, implementasi program ini terus digulirkan pada semua satuan pendidikan meski pada awal pelaksanaannya dilakukan secara bertahap. MAN Model Manado sebagai salah satu satuan pendidikan yang cukup ternama dan favorit dikalangan masyarakat Manado dewasa ini, juga telah menjadi pendidikan karakter sebagai bagian yang tak terpisahkan dari kurikulum yang telah ditetapkan bersama oleh komponen madrasah terutama guru sebagai pelaksana dari pada program pendidikan karakter ini.

Pendidikan karakter ini diintegrasikan pada kurikulum MAN Model Manado sejak tahun ajaran 2011-2012 pada semister genap. Program pengintergasian pendidikan karakter ini digodok oleh masing-masing guru melalui wadah MGMP Madrasah. MGMP MAN Model Manado dikelompokkan berdasarkan MGMP rumpun mata pelajaran, mislanya MGMP rumpun IPA, IPS, Bahasa, Agama, dan rumpun muatan lokal. Oleh MAN Model Manado pendidikan budaya dan karakter bangsa tersebut memiliki fungsi penanaman, penumbuhan, pengembangan, dan pemantapan. Fungsi tersebut diantaranya mengembangkan potensi dasar siswa agar memiliki akhlak yang berhati baik, berpikiran baik, dan berperilaku baik, memperkuat dan membangun perilaku siswa yang multikultur dengan kondisi Kota Manado dimana masyarakatnya sangat majemuk, sehingga dapat meningkatkan peradaban yang kompetitif dalam pergaulan siswa kelak.

Fungsi pendidikan budaya dan karakter bangsa oleh MAN Model Manado memiliki tujuan utama, yaitu membentuk karakter siswa yang religius, tangguh, kompetitif, bermoral, bertoleran yang tinggi, bergotong royong, beriiwa patriotik, berkembang dinamis, berorientasi ilmu pengetahuan dan teknologi yang semuanya dilandasi oleh iman dan takwa kepada Tuhan yang Maha Esa.

Selain itu, pengembangan pendidikan karakter pada MAN Model Manado menurut Dra. Sarpin Hamzah juga didasari dari visi dan misi MAN
Model sendiri, yakni visi "mantap dalam iman dan taqwa, unggul dalam ilmu dan teknologi, berpartisipasi dalam olah raga dan seni". Dan misi "1) meningkatkannya pengalaman iman dan taqwa, 2) meningkatnya penguasaan sains dan teknologi, 3) meningkatnya tenaga profesionalisme tenaga pendidik dan kependidikan, 4) meningkatnya sarana dan prasarana dalam menunjang pendidikan, 5) meningkatnya hubungan kerjasama dengan masyarakat dan isntansi terkait, dan 6) meningkatnya prestasi olah raga dan seni”.

Konsep pendidikan dengan karakter lokal dapat digali berdasarkan budaya dan adat istiadat. Melalui budaya pemberdayakan tradisi lisan sebagai sumber-sumber nilai, norma dan pesan yang terkandung di dalamnya. Pesan tersebut terkait dengan segi kehidupan masyarakatnya. Misalnya, untuk kota Manado terdapat slogan sebagai filsafat hidup masyarakat Minahasa yang dipopulerkan oleh Sam Ratulangi "Si Tou Timou Tumou Tou" yang artinya manusia hidup untuk memanusikan orang lain atau orang hidup untuk menghidupkan orang lain. Untuk Kota Manado banyak pesan yang sarat dengan pesan moral dan motivasi hidup yang berkembang. (Taufik B. Raharja, wawancara 17/7/ 2013).

Masyarakat Kota Manado merupakan masyarakat pluralis. Dengan kondisi mampu membuktikan diri dengan minimnya angka kerusuhan etnis dan ini merupakan salah satu nilai moral dan menjadi modal dasar pembangunan Kota Manado. Nilai kerukunan dan kegotongroyongan telah mampu membina suatu hubungan harmonis antar etnis yang ada di Kota Manado. Nilai-nilai ini terkadung dalam istilah Mapalus. Mapalus berarti saling membantu untuk mengisi yang kosong; kemudian diartikan untuk bekerja bergotongroyong untuk berbagai pekerjaan. Dasar Mapalus dikerangkai oleh keyakinan, bahwa sosok manusia yang terdiri atas tiga unsur, yaitu tubuh atau keketer, roh atau pemendam, dan jiwa atau gegenang. Pada hakikatnya adalah tunggal dari satu darah belaka atau matuari, yang oleh karenanya wajib secara suka rela untuk melakukan pekerjaan bergotongroyong demi kesejahteraan bersama (Tambayong, 2007:190).

Karakter budaya masyarakat Manado ini memiliki nilai-nilai filosofis tinggi, prinsip ini berlandaskan pada karakter religi (yang menghormati leluhurnya) dan karakter sosial 
(dengan keberagaman suku dan etnis) hal ini dilatarbelakangi karakter kebersamaan. Dalam pengembangan dan pengimplementasian pembelajaran, budaya lokal ini dapat menjadi salah satu bahan penguatan bagi pembelajaran khususnya di madrasah.

\section{Integrasi Pendidikan Karakter Dalam Pembelajaran}

Proses pengembangan nilai-nilai Karakter oleh MAN Model Manado yang menjadi landasan dari karakter itu melalui proses yang berkelanjutan dan memerlukan waktu, pendidikan karakter khusus dalam pembelajaran diimplementasikan melalui semua mata pelajaran yang ada dalam kurikulum MAN Model Manado mislanya: rumpun IPS (mata pelajaran kewarganegaraan, sejarah, geografi, ekonomi, sosiologi, antropologi, penjaskes, dan seni) rumpun bahasa (bahasa Inggris, bahasa Indonesia, bahasa Arab, bahasa Jepang, dan bahasa Jerman), rumpun IPA, misalnya: (matematika, kimia, biologi, fisika,), rumupun Agama, misalnya: (aqidah akhlak, quran hadits, ilmu kalam, ilmu tafsir, SKI, dan fiqh). Dan Muatan Lokal (tata busana, tata boga, mebel, dan pertamanan).

Kurikulum pendidikan karakter berupaya mengembangan nilai-nilai yang menjadi dasar bagi pendidikan budaya dan karakter bangsa tersebut. Dengan terobosan kurikulum yang demikian, nilai dan karakter yang dikembangkan pada diri siswa akan sangat kokoh dan memiliki dampak nyata dalam kehidupan, bermasyarakat dan berbangsa.

Pengembangan pendidikan budaya dan karakater bangsa pada mata pelajaran di MAN Model Manado diintegrasikan dalam pokok bahasan. Nilai dari masing-masing karakter tersebut tercantum dalam silabus dan RPP. Penentuan nilai karakter dalam silabus tersebut direncanakan oleh masing-masing guru mata pelajaran MAN Model Manado dengan tahapan: menelaah materimateri yang akan diajarkan pada mata pelajaran bersangkutan, menentukan Standar Komptensi (SK) dan Kompetensi Dasar (KD) pada standar isi untuk menentukan nilai-nilai budaya dan karakter bangsa yang sesuai dengan $\mathrm{SK}$ dan $\mathrm{KD}$, memasukkan nilai-nilai budaya dan karakter bangsa dalam kolom silabus, mencantumkan nilai-nilai karakter dalam RPP (dominan guru mencantumkan nilai karakter lebih dari satu karakter), pada proses pembelajaran guru dan peserta didik secara aktif yang melakukan pengembagan nilai-nilai karakter dan mengimplementasikannya dalam perilaku yang sesuai pada kehidupan sehari-hari.
Penerapan nilai karakter pada silabus dan RPP masing-masing guru mata pelajaran MAN Model Manado dalam satu standar kompetensi dan kompetensi dasar dominan lebih dari satu nilai karakter, bahkan ada yang mencapai lima sampai enam karakter yang ingin dicapai. Proses pembelajaran pendidikan karakter dilakukan berorientasi pada pengetahuan, tetapi juga prilaku/ sikap siswa. Oleh karenanya, guru perlu menambah orientasi pada tujuan setiap mata pelajaran atau sejumlah kegiatan belajar dengan pencapaian sikap atau nilai tertentu, penambahan orientasi nilai ini, dirasakan oleh sebagian guru sangat sulit terkait bagaimana secara teknis orientasi nilai karakter ini dikembangkan dalam proses pembelajaran.

Teknik pembelajaran sebagai titik tolak dilaksanakan aktifitas belajar pada siswa dapat menggunakan berbagai media baik berupa teks lisan maupun tertulis, grafik, diagram, gambar, model, chart, benda sesungguhnya, film, dan sebagainya, memperkenalkan nilai-nilai karakter tersebut adalah yang tidak hanya menyajikan tetapi yang terpenting adalah bagaimana nilai-nilai tersebut diimplementasikan pada kehidupan sehari-hari.

Proses pembelajaran adalah merupakan proses interaksi yang dilakukan oleh siswa dan guru, dengan pembelajaran tersebut tentunya akan mencapai tujuan tertentu. kegiatan belajar yang dapat membantu siswa menginternalisasi nilainilai melalui aktivitas-aktivitas yang mendorong terjadinya belajar yang berpusat pada siswa. Pembelajaran yang berpusat pada siswa secara otomatis akan membantu siwa memperoleh nilainilai yang ingin dicapai. kegiatan belajar tersebut dapat melalui berbagai metode pembelajaran, diantaranya: metode ceramah, tanya jawab, diskusi, eksperimen, observasi, debat, presentasi oleh siswa, dan karya wisata serta berbagai metode lain yang dikembangkan oleh guru, atau metode variasi dari beberapa metode.

Kegiatan pelaksanaan pembelajaran oleh guru MAN Model Manado memiliki beberapa tahapan diantaranya kegiatan pendahuluan, inti, dan penutup, Pada tahapan pelaksanaan pembelajaran tersebut memiliki aspek-aspek kegiatan, yakni:

Kegiatan Pendahuluan. Pada kegiatan pendahuluan merupakan kegiatan awal dalam suatu pembelajaran yang ditujukan untuk membangkitkan motivasi dan memfokuskan perhatian siswa untuk berpartisipasi aktif dalam proses pembelajaran. Pada pelaksanaan 
pembelajaran, dalam kegiatan pendahuluan guru: 1) guru melakukan apersepsi (mengemukakan materi yang akan diajarakan dan mengaitkan dengan materi yang telah lalu), memotivasi siswa untuk mengikuti pembelajaran, 2) memancing siswa terhadap materi yang akan diajarkan melalui pertanyaan-pertanyaan 3) mengungkapkan standar kompetensi dan kompetensi dasar yang akan dicapai. Pada kegiatan pendahuluan ini jika memungkinkan waktu yang akan digunakan lebih dari satu jam pelajaran maka dominan guru MAN Model mengabsen/ mengecek kehadiran siswa di kelas. Pada kegiatan pendahuluan ini, sebagian guru MAN Model memberikan informasi kepada siswa nilai-nilai karakter yang akan dicapai pada materi pembelajaran yang akan dipelajari.

Implementasi pendidikan karakter oleh guru dalam mengenalkan nilai-nilai tersebut, tentunya harus diawali dari nilai-nilai yang dicontohkan oleh guru bersangkutan terlebih dahulu, misalnya sebagai berikut, diantaranya: guru datang tepat waktu (disiplin), mengucapkan salam ketika memasuki kelas dan memimpin doa sebelum membuka pelajaran (religius), mengecek kehadiran siswa (disiplin), mendoakan siswa yang tidak hadir karena sakit atau karena halangan lainnya (religius), mengecek siswa datang tepat waktu, menegur siswa yang terlambat (disiplin), dan menjelaskan materi yang dipelajari dengan karakter yang ingin dicapai sesuai dengan RPP.

Kegiatan inti. Pada kegiatan pembelajaran inti oleh guru dilakukan secara interaktif, menyenangkan, memotivasi siswa untuk aktif, serta memberikan ruang yang cukup bagi kreativitas sesuai dengan bakat, dan minat siswa. Pada kegiatan inti terdapat tahapan eksplorasi, elaborasi, dan konfirmasi. Tahap eksplorasi, memberikan peluang kepada siswa mencari informasi tentang materi yang dipelajari dan guru mengaitkan dan mengembangakan materi tersebut dengan nilainilai karakter yang akan dicapai misalnya karakter tanggungjawab, kreatif, kerjasama, dan karakter lain yang terkait materi. Memfasilitasi terjadinya interaksi antar siswa serta antara siswa dengan guru, lingkungan, dan sumber belajar lainnya (kerja sama, saling menghargai, peduli lingkungan); melibatkan siswa secara aktif dalam setiap kegiatan pembelajaran (rasa percaya diri, mandiri); dan memfasilitasi siswa melakukan praktek di laboratorium, (secara individu dan kelompok). Tahap elaborasi, pada tahapan elaborasi, guru berusaha untuk memberikan peluang kepada siswa untuk lebih kreatif dalam pembelajaran misalnya memberi peluang kepada siswa menyelesaikan tugas yang diberikan, mislanya diskusi untuk memunculkan ide/gagasan, baik secara lisan maupun tertulis (kerjasama, tanggung jawab, percaya diri, kritis, menghargai pendapat, santun); memberi kesempatan untuk berpikir, menganalisis, menyelesaikan masalah, dan bertindak tanpa rasa takut. Tahap konfirmasi, pada tahap ini, memberikan umpan balik positif dan penguatan terhadap siswa (percaya diri, saling menghargai, santun, kritis, logis); memberikan konfirmasi terhadap hasil pembahasan siswa, dan melakukan refleksi untuk kelebihan dan kekurangannya memberikan motivasi kepada siswa yang kurang atau belum berpartisipasi aktif (peduli, percaya diri).

Pada pelaksanaan pembelajaran, proses pembelajaran pada tahap eksplorasi, elaborasi, dan konfirmasi, yang dapat membantu siswa menginternalisasi nilai-nilai karakter ini dapat terwujud, apabila guru dapat memilih suatu pendekatan pembelajaran dimana peserta didik memiliki hasil yang komprehensif tidak hanya pada tataran kognitif (olah pikir), tetapi pada tataran afektif (olah hati, rasa, dan karsa), serta psikomotor (olah raga).

Kegiatan penutup. Penutup merupakan kegiatan untuk mengakhiri pembelajaran dalam bentuk memberikan kesimpulan dari materi yang telah dipelajari bersama-sama oleh guru dan siswa, melakukan program pengayaan selanjutnya atau memberikan tugas individual maupun kelompok pada siswa (karakter disiplin, tanggung jawab, mandiri, kerja keras), merancang kegiatan pembelajaran berikutnya (karakter rasa ingin tahu, tanggung jawab, dan karakter lain).

Evaluasi/penilaian merupakan kegiatan untuk menentukan pencapaian hasil pembelajaran. Penilaian hasil belajaran dari mata pelajaran yang telah diberikan pada umumnya oleh guru MAN Model melalui evaluasi harian, bulanan (atau selesai satu pokok bahasan), dan semester baik berbentuk lisan maupun tulisan.

Terkait evaluasi pendidikan karakter yang telah diajarkan, menurut Anis Toma, M.Pd evaluasi bagi pendidikan karakter lebih kepada penilaian afektif/prilaku keseharian siswa secara nyata. Poitnya penilaian pendidikan karakter semestinya harus jelas. Secara formal prilaku ini sulit untuk 
dinilai. Misalnya pada asepk kerapian, semestinya bagi guru nilai-nilai ini bisa dibuatkan format dan disosialisasikan dan berbeda pada aspek kognitif jelas materi evaluasi. Pada aspek afektif sedikit susah untuk dievaluasi, dan hanya memungkinkan dilakukan dengan melihat secara umum dari prilaku siswa. Selama ini penilaiannya afektif pada siswa MAN Model hanya diberikan pada kategori $\mathrm{A}=$ sangat baik, $\mathrm{B}=$ baik, $\mathrm{C}=$ cukup, dan $\mathrm{D}=$ kurang pada rapor siswa bersangkutan.

Lebih lanjut menurut Taufik B. Rahaja, S.Pd, untuk evaluasi/penilaian implementasi nilai karakter yang telah dilakukan terhadap siswa berdasarkan nilai karakter yang ada secara formal belum dilakukan, tetapi secara umum penilaian karakter tersebut masuk pada penilaian sikap/ prilaku (afektif) di dalam rapor masing-masing siswa. Penilaian ini diberikan oleh masing-masing guru (wali kelas). Pada penilaian afektif siswa terdapat 5 indikator penilaian, masing-masing indikator terdapat beberapa aspek penilaian, yakni: aspek kehadiran (1) sangat tidak rajin, 2) tidak rajin, 3) rajin, dan 4) sangat rajin)). Keaktifan mengumpulkan tugas (1) tidak aktif, 2) cukup, 3) aktif, dan 4) sangat aktif). Keaktifan dalam pembelajaran (1) tidak tepat waktu, 2) kurang tepat waktu, 3) tepat waktu). Kerjasama kelompok (1) tidak aktif, 2) cukup aktif, 3) aktif, 4) sangat aktif). Kerapian (1) kurang rapi, 2) cukup rapi, 3) rapi, dan 4) sangat rapi. Nilai pada masing-masing aspek tersebut adalah untuk nilai $\mathrm{A}=90-100, \mathrm{~B}=80-89$, $\mathrm{C}=70-79, \mathrm{D}=60-69$.

\section{Pembentukan Nilai Karakter}

Perencanaan dan pelaksanaan pendidikan budaya dan karakter bangsa dilakukan pada semua komponen madrasah misalnya oleh kepala madrasah, tenga pendidik, siswa, dan tenaga kependidikan (TU) secara bersamasama sebagai suatu komunitas di dalam satuan pendidikan madrasah dan diterapkan ke dalam kurikulum. Misalnya dalam program pembelajaran, pengembangan diri, perencanaan dan pelaksanaan pendidikan budaya dan karakter bangsa dilakukan melalui pengintegrasian ke dalam kegiatan seharihari di madrasah. Misalnya pada kegiatan rutin, spontan, keteladanan, dan pengkondisian.

Kegiatan rutin madrasah. Kegiatan rutin di MAN Model merupakan kegiatan yang dilakukan peserta didik secara terus menerus dan konsisten setiap saat. Misalnya pada kegiatan upacara setiap senin pagi, upacara setiap tanggal 17, upacara pada hari besar kenegaraan, pemeriksaan kelengkapan atribut sekolah (yang betugas adalah OSIS dan anggotanya), kerapian dan kebersihan pakaian/ badan (kuku, telinga, rambut, dan lain-lain) setiap hari Senin, beribadah bersama atau shalat setiap zuhur secara berjamaah di masjid MAN Model Manado. Kegiatan shalat berjamaah pada hari Jumat untuk siswa laki-laki, dan bagi siswi dilakukan kegiatan rutin yakni kajian keputrian di aula MAN Model. Kajian keputrian ini diikuti oleh semua siswi MAN Model yang didamping oleh guru pembina. Pada kegiatan keputrian dilakukan kajian seputar masalah keputrian oleh siswa yang telah ditugasi sebelumnya. Berdoa waktu mulai dan selesai pelajaran, mengucap salam bila bertemu guru, tenaga kependidikan, teman, dan orang yang lebih tua. Kegiatan rutin lainnya adalah berdoa pada saat memulai dan mengakhiri pembelajaran.

Kegiatan spontan. Kegiatan spontan merupakan kegiatan yang dilakukan secara spontan dan repleks. Kegiatan-kegiatan spontan seperti dilakukan oleh siswa baik berupa perbuatan yang sedikit tidak sesuai dengan kebiasaan/menyalahi kebiasaan, biasanya pada saat guru dan tenaga kependidikan yang lain mengetahui adanya perbuatan yang kurang baik dari peserta didik yang harus dikoreksi pada saat itu juga. Apabila guru mengetahui adanya perilaku dan sikap yang kurang baik maka pada saat itu juga guru harus melakukan koreksi sehingga peserta didik tidak akan melakukan tindakan yang tidak baik itu. Misalnya: membuang sampah tidak pada tempatnya, merusak taman, mencoret-coret dinding, merokok, mengganggu teman, berkelahi, memalak, tidak sopan terhadap guru maupun teman, mencuri, dan tidak memakai seragam.

Kegiatan spontan juga dinampakkan kepada peserta didik yang memiliki prestasi dan prilaku dalam berbagai hal terutama prestasi dalam mengharumkan nama madrasah, misalnya: berhasil dalam memperoleh prestasi dalam perlombaan bidang akademik, olah raga atau kesenian, berani menentang atau mengkoreksi perilaku teman yang tidak terpuji, rela berbagi dan saling tolong menolong pada saat ada teman yang terkena musibah dengan memberi sumbangan, bakti sosial ke pantiasuhan dan masjid.

Keteladanan. Keteladanan adalah perilaku dan sikap guru dan tenaga kependidikan yang lain dalam memberikan contoh terhadap tindakan-tindakan 
yang baik sehingga diharapkan menjadi panutan bagi peserta didik untuk mencontohnya. Jika guru dan tenaga kependidikan yang lain menghendaki agar peserta didik berperilaku dan bersikap sesuai dengan nilai-nilai budaya dan karakter bangsa maka guru dan tenaga kependidikan yang lain adalah orang yang pertama dan utama memberikan contoh berperilaku dan bersikap sesuai dengan nilai-nilai itu. Misalnya, berpakaian rapi, datang tepat pada waktunya, bekerja keras, bertutur kata sopan, kasih sayang, perhatian terhadap peserta didik, jujur, dan saling menjaga kebersihan pada semua komponen pendidikan.

Pengkondisian. Untuk mendukung keterlaksanaan pendidikan budaya dan karakter bangsa, oleh MAN Model Manado mengkondisikannya dengan melengkapi fasilitas sebagai pendukung kegiatan tersebut. Sekolah harus mencerminkan kehidupan nilai-nilai budaya dan karakter bangsa yang diinginkan. Misalnya, toilet yang selalu bersih, tempat cuci tangan pada masingmasing kelas, bak sampah ada di berbagai tempat (sampai kering dan basah) dan selalu dibersihkan, sekolah terlihat rapi dan fasilitas bersama seperti masjid, aula dan fasilitas belajar lainnya seperti laborarotium, ruang keterampilan, dan lain-lain. Kemudian mengkondisikan poster pancasila dan presiden/wakil pada masing-masing kelas, mengkodisikan visi misi madrasah, mengkodisikan budaya malu yang sudah menjadi ketetapan madrasah oleh OSIS MAN Model Manado, yakni: malu melanggar tata tertib madrasah, malu malas belajar, malu dimarahi guru, malu mendapat hukuman guru, malu berkata bohong, malu bersikap sombong, malu menyontek, malu mendapat nilai kurang, malu berlaku curang, dan malu prestasi menurun.

\section{Pendidikan Karakter Pada Kegiatan Pengembangan Diri/Ekstrakurikuler}

Pengembangan diri adalah kegiatan yang bertujuan untuk memberikan kesempatan kepada peserta didik untuk mengembangkan dan mengekspresikan diri sesuai kebutuhan, bakat, dan minat setiap peserta didik sesuai dengan kondisi MAN Model Manado. Kegiatan pengembangan diri dilakukan melalui kegiatan pelayanan konseling yang berkenaan dengan masalah diri pribadi dan kehidupan sosial, belajar, dan pembentukan karakter dan karier peserta didik. Pengembangan diri bagi peserta didik MAN Model Manado terutama ditujukan untuk pengembangan kreativitas dan bimbingan karier.

Kegiatan pengembangan diri difasilitasi dan dibimbing oleh konselor, guru, atau tenaga kependidikan yang dapat dilakukan dalam bentuk kegiatan eksrakurikuler. Kegiatan ekstrakurikuler merupakan kegiatan pendidikan di luar jam pelajaran yang merupakan bagian integral dari kurikulum madrasah dan ditunjukkan untuk membantu perkembangan siswa. Secara khusus kegiatan ekstrakurikuler dimaksudkan untuk menumbuhkembangkan bakat, minat, kreativitas, kompetensi dan kebiasaan dalam kehidupan, kemampuan keagamaan, kemampuan sosial, kemampuan belajar, kemampuan memecahkan masalah, kemandirian, dan kemampuan lain yang mendukung menemukan jati diri/karakter siswa. Kegiatan ekstrakurikuler dan masing-masing nilai karakter yang dikembangkan MAN Model Manado:

Kegiatan keagamaan (Sanggar At Tanwir) terdiri dari kegiatan tilawah, syahril quran, fahmil quran, khottil quran, puitisasi quran, samrah, qasidah, dan nasyid (karakter pengembangan di antaranya: religius, tangung jawab, percaya diri, disiplin, kerja keras, pantang menyerah). Kegiatan keolahragaan yakni: futsal/sepak bola, bulu tangkis, bola basket, bola voli, tenis meja, dan catur (karakter pengembangan jujur, sportif, disiplin, kerja keras, kerjasama, percaya diri, menghargai prestasi, dan tanggung jawab). Kegiatan kepemimpinan, di antaranya: paskibraka, Palang Merah Indoensia, pramuka, dan sispala (karakter pengembangan: percaya diri, kerjasama, demokrasi, peduli sosial dan lingkungan, toleransi, kerja keras, disiplin, dan komunikatif). Kegiatan kesenian, yakni: teater dan marching band (karakter yang dikembangkan adalah mandiri, percaya diri, disiplin, tanggungjawab, dan kerjasama).

Setiap peserta didik diberikan kesempatan untuk memilih jenis esktakurikuler yang ada di MAN Model Manado. Segala aktivitas peserta didik berkenaan dengan kegiatan ekstrakurikuler di bawah pembinaan dan pengawasan guru pembina yang telah ditugasi oleh madrasah. Pendidikan karakter sudah menjadi program MAN Model yang dimasukan dalam setiap aspek kegiatan belajarmengajar di ruang kelas, praktek keseharian di sekolah, dan terintegrasi dengan setiap kegiatan ekstrakurikuler. Dan hal ini, diharapkan pada setiap siswa menerapkannya di sekolah, di rumah dan lingkungan sekitarnya. Semua aspek pendidikan 
mulai dari ruang kelas hingga lingkungan tempat tinggal harus tetap berkesinambungan dalam menjaga nilai-nilai pendidikan karakter tersebut.

\section{Pendukung dan Penghambat Implementasi Pendidikan Karakter Penghambat}

Guru/tenaga pendidik. Penerapan dan implementasi pendidikan karakter terhadap siswa hendaknya dimulai dari kesiapan guru dalam berbagai aspek. Guru hendaknya memiliki nilai lebih yang dapat dijadikan panutan dan tauladan bagi siswa. Kenyataan dewasa terdapat anggapan bahwa guru pada level integritas terhadap profesinya sedikit bergeser dan kehilangan ruh (karakter ihlasnya), hanya sebatas formalitas selesai tugas mengajar maka selesai tugas guru.

Sosialisasi dan teknik impelementasi pendidikan karakter masih sangat kurang pada semua lini (baik pada tataran pengambil kebijakan/ instansi terkait muapun pihak-pihak tekait lainnya). Wadah guru, pada asepk ini guru memerlukan wadah yang lebih intens dalam mengkomunikasi berbagai hal, khususnya pada implementasi pendidikan karakter secara teknis masih dirasakan sangat dangkal informasi yang diperoleh.

Monitoring dan evaluasi perlu ditingkatkan dalam mengontrol proses pembelajaran terutama implementasi berkaitan dengan pendidikan karakter. Ini cukup berbeda dengan program kurikulum KTSP ketika digulirkan, cukup intens dalam sosialisasi maupun implemetansi pada satuan pendidikan yang ada.

Siswa, pada tataran siswa masih terdapat siswa yang sering melakukan hal-hal yang kurang berkenan tetapi masih dalam batas kewajaran sebagai kenakalan remaja. Hal ini menjadi perhatian guru dengan keberadaan siswa yang dalam masa perkembangan remaja terutama dalam mengawal pembentukan karakter bagi siswa.

Pada materi-materi saat penyusunan silabus/ RPP pada mata pelajaran tertentu terkadang masih sulit untuk menentukan dan mengaitkan karakter yang akan dicapai. Terutama dalam membahas berkaitan dengan teori. Pendidikan dan latihan, pada kegiatan pendidikan dan latihan berkaitan dengan pendidikan karakter belum semua guru pernah mengikuti kegiatan tersebut, hanya beberapa guru yang pernah ikut baik pada kegiatan diklat maupun workshop.

Sistem madrasah, sebagai suatu sistem yang saling terkait dalam berbagai komponen terutama dalam menjalankan aturan yang telah ditetapkan dan menjadi rutinitas madrasah hendaknya dijalankan dangan kerjasama oleh semua komponen madrasah.

\section{Pendukung}

Sumber daya pendidik cukup mendukung untuk proses pembelajaran, yang terpenting adalah suport bagi guru itu sendiri terutama dalam bentuk pembinaan komptensi guru itu sendiri. Keberdaan guru-guru madrasah yang saling mendukung dan mengisi satu dengan yang lainnya baik yang terwadahkan lewat MGMP maupun tidak terwadahkan.

Motivasi kepala sekolah, kepemimpinan yang ditunjukkan oleh kepala madrasah cukup memberi perhatian terhadap berbagai aspek terutama bagi peningkatan mutu pendidikan madrasah secara keseluruhan. Orang tua siswa. Dorongan dari orang tua siswa terhadap terhadap perkembangan madrasah cukup memberi perhatian, ini terlihat pada berbagai kegiatan yang dilakukan oleh madrasah cukup diresponi positif oleh orang tua siswa.

\section{PENUTUP}

Implementasi pendidikan karakter dimaksudkan untuk mendukung perwujudan cita-cita pembangunan karakter sebagaimana diamanatkan dalam Pancasila dan Pembukaan UUD 1945 serta mengatasi permasalahan kebangsaan saat ini, telah dilakukan sosialisasi oleh berbagai pihak khusunya Kementerian Agama dan jajarannya (mapenda), dan telah menjadi mata ajar pada Balai Diklat Keagaman Manado, peran pengawas madrasah juga turut melakukan penerapan pada satuan pendidikan, dan terhadap satuan pendidikan juga melakukan hal yang sama yang terhimpun dalam wadah MGPM madrasah. Dalam implementasi pendidikan budaya dan karakter bangsa merupakan salah satu upaya untuk mencegah terjadinya degradasi nilai-nilai etika dan moral di kalangan siswa. Keberhasilan dalam membangun karakter siswa, secara otomatis akan membantu keberhasilan membangun karakter bangsa. Oleh karena itu, kemajuan suatu bangsa juga akan tergantung bagaimana karakter orangorangnya. Dengan demikian pendidikan karakter adalah penting dalam membangun moral dan kepribadian bangsa. Madrasah dalam membangun karakter melibatkan aspek pengetahuan (kognitif), 
aspek perasaan (afektif), dan aspek tindakan atau aksi (psikomotorik). Untuk mengimplementasikan pendidikan budaya dan karakter bangsa tersebut melalui pembelajaran, yaitu bagaimana menanamkan kebiasaan tentang nilai-nilai budaya dan karakter, mampu merasakan (afektif) nilai yang baik dan biasa melakukannya (psikomotor) melalui pembelajaran maupun pengembangan pada kegiatan-kegiatan ekstrakurikuler madrasah.

Faktor pendukung dan penghambat implementasi pendidikan karakter pada MAN Model Manado di antaranya: penghambat: Kesiapan guru/tenaga pendidik, sosialisasi dan teknik impelementasi pendidikan karakter masih sangat kurang, wadah guru yang lebih intens dalam mengkomunikasi berbagai hal, monitoring dan evaluasi oleh pihak terkait, siswa, pendidikan dan latihan (khusus pendidikan karakter belum semua guru mengikuti diklat), dan sistem madrasah (rutinitas madrasah dijalankan dangan kerjasama oleh semua komponen madrasah). pendukung: Sumber daya pendidik, kepemimpinan kepala madrasah, dan orang tua siswa.

\section{UCAPAN TERIMA KASIH}

Terima kasih penulis sampaikan kepada seluruh informan yang telah memberikan peluang kepada peneliti melakukan penelitian ini di MAN Model Manado terkhusus kepada Ibu Dra. Hj. Sarpin Hamzah dan Bapak Taufik B Raharja, S. Pd berserta jajaran yang telah sudi meluangkan waktunya dalam memberi informasi pada penelitian ini. Kepada Kemenag Provinsi Sulawesi Utara, Pengawas Madrasah, dan Balai Diklat Keagamaan Manado yang telah memberikan peluang melakukan penelitian, petunjuk, dan informasi untuk penelitian ini. Kepada teman-teman peserta OJS dan rekan-rekan peneliti yang telah memberikan buah pikiran, saran dan kritikan dalam tulisan ini. Kepada tim redaksi Alqalam terima kasih banyak untuk termuatnya tulisan ini.

\section{DAFTAR PUSTAKA}

Hamid, Hamdani. 2013. Pendidikan Karakter Perspektif Islam. Cet. I. Bandung: Pustaka Setia.

Husaini, Adian. 2010. Pendidikan Islam Membentuk Manusia Berkarakter dan Beradab. Jakarta: Cakrawala Publising.

Kementerian Pendidikan Nasional. 2010. Bahan Pelatihan Pengembangan Pendidikan Budaya dan Karakter Bangsa. Jakarta: Badan Penelitian dan Pengembangan Pusat Kurikulum.

Kementerian Pendidikan Nasional. 2010. Desain Induk Pendidikan Karakter.

Koesoema. A, Doni. 2012. Pendidikan Karakter Utuh dan Menyeluruh. Yogyakarta: Kanisius.

Mu'in, Fatchul. 2011. Pendidikan Karakter Konstruksi Teoritik dan Prakti., Cet.II. Yogjakarta: Ar-Ruzz Media.

Mulyasa, E. 2011. Manajemen Pendidikan Karakter. Jakarta: Bumi Aksara.

Nashir, Haedar. 2013. Pendidikan Karakter Berbasis Agama dan Budaya. Yogyakarta: Multi Presindo.

Saimroh, dkk (Tim Peneliti Balai Litbang Agama Jakarta). 2013. Pendidikan Karakter di Madrasah Ibtidaiyah Unggulan. Cet.I. Jakarta: Balai Penelitian dan Pengembangan Agama Jakarta.

Sugiyono. 2010. Metode Penelitian Kuantitatif dan Kualitatif dan $R$ \& $D$. Bandung: Alfabeta.

Tambayaong, Yapi. 2007. Kamus Bahasa dan Budaya Manado. Jakarta: PT. Gramdia Pustaka Utama.

Undang-Undang Nomor 20 Tahun 2003. SISDIKNAS.

Zainal Fitri, Agus. 2012. Pendidikan Karakter Berbasis Nilai dan Etika di Sekolah. Yogyakarta: Ar-Ruzz Media.

Zubaedi. 2011. Desain Pendidikan Karakter, Konsepsi dan Aplikasi dalam Lembaga Pendidikan. Jakarta: Kencana. 